\title{
The Difference Effect of Recovery in Warm Water and Aroma Therapy Sauna Recovery against Decreased Lactic Acid Levels after Submaximal Physical Activity
}

\author{
Ardo Yulpiko Putra ${ }^{1}$, Hari Setijono ${ }^{2}$, Edy Mintarto ${ }^{2}$ \\ ${ }^{1}$ Postgraduate Program in Sports Science, Universitas Negeri Surabaya, Indonesia \\ ${ }^{2}$ Department of Sports Coaching, Faculty of sport Sciences, Universitas Negeri Surabaya, Indonesia. \\ Email: ardoputra16070946018@mhs.unesa.ac.id
}

\begin{abstract}
:
Recovery is one way to reduce levels of blood lactic acid after exercising. There are several types of recovery, namely warm water recovery and aroma therapy sauna recovery. However, both types are not very well-known. This study aims to look at the differences in the effect of warm water recovery and aroma therapy sauna recovery on decreasing blood lactic acid levels after submaximal physical activity. The study design used is the randomized pre-test and post-test group design. This study used 18 people per group consisted of men aged 19 to 21 years. Subjects were divided into 2 groups K1 and K2; K1 is warm water recovery group and K2 is aroma therapy sauna recovery group. Both groups were given maximal $85 \%$ heart rate of submaximal physical activity treatment. The submaximal form of physical activity is using ergo cycle. The warm water recovery and aroma therapy sauna recovery were done after the submaximal physical activity. The warm water recovery is in the form of soaking in warm water and the aroma therapy sauna recovery is in the form of only staying silent and still in the sauna for 5 minutes long. The data obtained from the results of the study were processed using the SPSS 20 program statistics. The results showed that the mean of blood lactic acid level in the pre-test was $9.36 \pm 1.82 \mathrm{mMol} / \mathrm{L}$, the K1 group post test1 was $3.75 \pm 1.04 \mathrm{mMol} / \mathrm{L}$, group K1 post test2 $2.70 \pm 0.88 \mathrm{mMol} / \mathrm{L}$, group K2 post test1 $5.28 \pm 1.35 \mathrm{mMol}, \mathrm{L}$, group K2 post test2 $3.12 \pm 1.01 \mathrm{mMol} / \mathrm{L}$. Data were processed using descriptive and inferential statistics (normality test, homogeneity test, paired $t$ and free $t$-test) with a significance level of $p<0.05$. Paired t-test results showed a significant decrease in lactic acid $(0,000)$ and free T active delta 1 and delta 1 passive $p=0.031$, delta 3 active and delta 3 passive $p=0.015$ which means there is a significant difference between the warm water recovery group and the aroma therapy sauna recovery group. Thus from the results of this study it can be concluded that the decrease in blood lactic acid levels is greater in the warm water type of recovery compared to the aroma therapy sauna type of recovery.
\end{abstract}

Keywords:

lactic acid; warm water recover; aroma therapy sauna recovery

\section{Introduction}

In improving sports achievements, an athlete must continue to practice in order to achieve maximum results. However, doing training without recovery will not achieve the maximum results expected because it only improves the aspects of appearance without ever overcoming the fatigue (Russ Hall, Pyke, 1992). Recovery provides time to restore the body's condition back to its condition before the competition (Soekarman, 1991). This phase is a condition needed by the body to return to its original state. Imperfect recovery between one physical exercise with the next physical exercise or between one match with the next match will reduce the performance of an athlete (Patellongi, 2004). A perfect recovery will make an athlete return to its original state as before the competition started. 
During the recovery period there will also be the recovery of energy reserves, the removal of lactic acid from blood and muscles, and the recovery of glycogen reserves (Fox, 1993). Physical activity carried out with high intensity and continuously can cause increased levels of lactic acid in the blood and muscles (Fox et al, 1993). Increased levels of lactic acid will reduce blood $\mathrm{pH}$ and decrease blood $\mathrm{pH}$ and will cause a decrease in the speed of enzyme reactions in cells resulting in the reduction of the ability of metabolism and ATP production as one of the factors causing fatigue. To reduce fatigue that occurs, the levels of lactic acid in the blood and muscles must be immediately reduced to the normal threshold (Falk, 1995).

The parameters of lactic acid as an indicator of fatigue are reinforced by the opinion of Westerblad et al (2000) who explains in his research that muscle fatigue is caused by intracellular acidosis due to accumulation of lactic acid. Increased levels of lactic acid during strenuous activities caused by very high energy requirements are obtained anaerobically with the result of 2 ATP and the residual product in the form of lactic acid. This research has proven that the decrease in blood lactic acid levels after a short physical exercise with the warm water recovery (temperature $35^{\circ} \mathrm{C}-37^{\circ} \mathrm{C}$ ) is greater than that at room temperature water $\left(<31^{\circ} \mathrm{C}\right)$ that has been done (Rachmaniah, 2010).

Recovery can be done by the warm water recovery and aromatherapy sauna recovery. For example, bathing in warm water can be done by actively swimming in place and by passively sitting still. According to Brook (1999) and Fox (1993) that form of warm water recovery will accelerate the recovery process of blood lactate levels when compared to the aromatherapy sauna recovery. Recovery can be done in various ways by reducing the burden of these activities, such as warm water recovering by cycling or going up and down the bench (Kumaidah, 2002). Recovery by doing massage (Prasetyo, 2008).

According to Peni (2008) from the Dharma Raya Lestari Jakarta clinic, water is the right therapeutic medium for the recovery of stiff or injured muscles and joints. Warm water has temperatures ranging from $31^{\circ} \mathrm{C}$ to $37^{\circ} \mathrm{C}$. This temperature range is quite safe and provides a relaxing effect, reduces pain, and has a physiological impact on the body, namely the impact on blood vessels. In addition, exercising in water has a positive impact on the heart, lung muscles, and breathing circulation for the better.

The temperature of $31^{\circ} \mathrm{C}$ also affects tissue oxygenation so that it can prevent muscle stiffness and relieve pain (Peni, 2008). One method that is not yet well known is the warm passive recovery. Warm water temperature will improve blood circulation and improve the performance of enzymes that work on the body's metabolism in producing ATP. Warming aromatherapy sauna involves a variety of equipment with several ways from the outside (external) to raise body temperature, including diathermy to heat the inner tissue, attached heating, steam baths, saunas and hot showers.

Although not many athletes practice it, their appearance or physical performance will increase compared to no warming at all if the body temperature is sufficiently increased with this method. The advantage of passive heating is that there is a possibility of reduced damage due to depletion of energy reserves, due to the insignificant amount of activity (Taylor, 2002).

Various studies that examine the form of effective recovery to reduce levels of lactate, namely the warm water recovery by going up and down the bench, further reduce levels of lactic acid when compared to the warm water recovery by cycling, have been done (Kumaidah, 2002). In the study by Afriwandi in 2007, active recovery after submaximal exercise reduced 
lactic acid levels faster than passive recovery. However, no research has been conducted on the effect of warm water recovery and saunas after submaximal physical activity in terms of fatigue with a human sample.

Lactic acid levels will decrease if physical activity is stopped or during recovery (Soekarman R, 1991). Based on these various things, a research was carried out to prove the effect of the difference in warm water recovery (temperature $35^{\circ} \mathrm{C}-37^{\circ} \mathrm{C}$ ) on the decrease in lactic acid levels after submaximal physical activity. The research is expected to be beneficial for the development of science that is contributing to the development of sports health science in Indonesia, which is to increase effective recovery methods in reducing levels of lactic acid in the exercise implementation in the field.

\section{Research Methods}

Based on the research formulation and hypothesis, the type and design of this study included experimental laboratory research with a "pretest-posttest control group design" (Zainuddin, 2000). The population of subjects in this study were students of the Department of Sport Science, Faculty of Sport Science, Surabaya State University, males, aged 21-23 years. The number of samples in this study was 18 people divided into two groups. To find out whether the use of 18 samples for each group met the research requirements, the results of the study were tested using a formula developed by Higgins \& Kleimbaun (1985). Subjects grouping was done using a simple random technique, i.e 18 selected samples from the population were divided into 2 groups by lottery. The K1 group for warm water recovery was of as many as 9 people and the K2 group for aromatherapy sauna recovery was of 9 people. The results of the study will be processed and analyzed through the help of the IBM SPSS statistical program 20 with a significance level of $5 \%$. The statistical tests used are 1 . Descriptive analysis. 2. Test for normality. 3. Paired T-Test. 4. T-free test.

\section{Discussion}

From the results of the study, the moderator variable weight (kilograms) height (centimeters) and mMol / 1 lactic acid levels were obtained. Descriptive statistical analysis is used to fulfill the requirements of the normality test, the paired T-test, and the free-T test.

Table 1. The Average of Lactic Acid Levels Variable

\begin{tabular}{ccc}
\hline Lactic Acid Levels Variable & n & Average +SD \\
\hline Pre-test Lactic Acid Levels (K1 and K2) & 9 & $9,36 \pm 1,82 \mathrm{mMol} / \mathrm{L}$ \\
Lactic acid levels & & \\
K1 Posttest 1 & 9 & $3,75 \pm 1,04 \mathrm{mMol} / \mathrm{L}$ \\
K1 Posttest 2 & & \\
K2 posttest 1 & & \\
K2 Posttest 2 & 9 & $5,28 \pm 1,35 \mathrm{mMol} / \mathrm{mol} / \mathrm{L}$ \\
& & $3,12 \pm 1,01 \mathrm{mMol} / \mathrm{L}$ \\
\hline
\end{tabular}




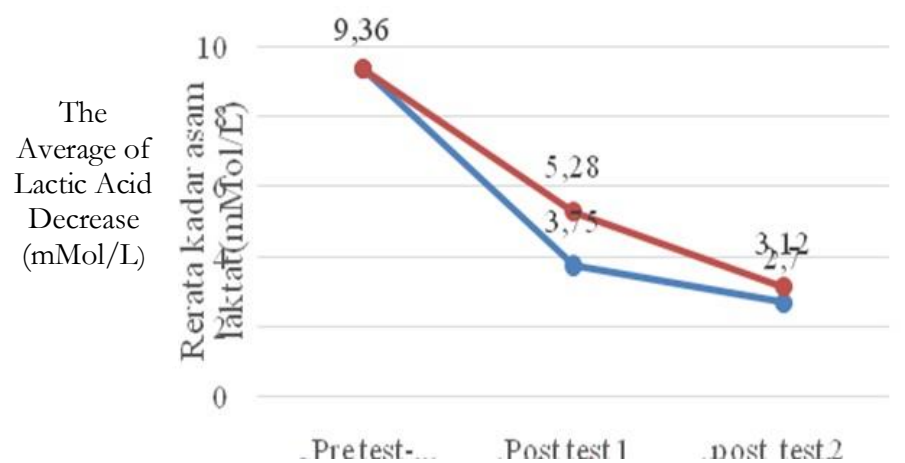

Figure 1. The average of lactic acid levels decrease

From the measurement of lactic acid levels immediately after 5 minutes of warm water recovery decreased from $9.36 \mathrm{mMol} / \mathrm{L}$ to $3.75 \mathrm{mMol} / \mathrm{L}$ and immediately after the aromatherapy sauna recovery decreased from $9.36 \mathrm{mMol} / \mathrm{L}$ to $5.28 \mathrm{mMol} / \mathrm{L}$. Lactic acid levels 10 minutes after recovery of warm water decreased from $3.75 \mathrm{mMol} / 1$ to $2.70 \mathrm{mMol} /$ 1. 10 minutes after recovery of sauna aromatherapy decreased from $5.28 \mathrm{mMol} / 1$ to 3.12 $\mathrm{mMol} / \mathrm{l}$.

Table 2. Normality Test Results

\begin{tabular}{cccc}
\hline Lactic Acid Levels Variables & $\mathbf{N}$ & Average+SD & $\mathbf{p}$ \\
\hline Pre test & 9 & $9,36 \pm 1,82$ & 0,766 \\
K1 : Posttest 1 & 9 & $3,75 \pm 1,04$ & 0,957 \\
K1 $:$ Posttest 2 & 9 & $2,70 \pm 0,89$ & 0,291 \\
K2 $:$ Posttest 1 & 9 & $5,29 \pm 1,35$ & 0,290 \\
K2 $:$ Posttest 2 & 9 & $3,12 \pm 1,02$ & 0,182 \\
\hline
\end{tabular}

\section{Data Normality Test uses the Shapiro-Wilk test}

The results of the normality test with Shapiro-Wilk showed that the levels of lactic acid variables in the two treatment groups were normally distributed $(p>0.05)$.

Table 3. Paired-T test results

\begin{tabular}{cccc}
\hline & & Delta Average+SD & p \\
\hline \multirow{2}{*}{ Warm Recovery } & Pretest - posttest 1 & $-5,60 \pm 1,98$ & 0,000 \\
& Pretest - Posttest 2 & $-6,66 \pm 1,57$ & 0,000 \\
& Posttest 1 - Posttest 2 & $-1,05 \pm 0,58$ & 0,001 \\
& Pretest - Posttest 1 & $-4,07 \pm 1,01$ & 0,000 \\
Aroma Therapy Sauna Recovery & Pretest - Posttest 2 & $-6,23 \pm 1,50$ & 0,000 \\
& & $-2,16 \pm 1.08$ & 0,000 \\
\hline
\end{tabular}

It shows the results of the value of $\mathrm{p}<0.05$ means the hypothesis is accepted. 


\subsection{Independent-T Test}

Independent-T test results to compare the decrease in levels of lactic acid between the warm water recovery group and the aromatherapy sauna recovery group.

\begin{tabular}{cclc}
\hline & Group & Delta Average \pm SD & p \\
\hline Delta 1 warm water & Pretest - K1 posttest 1 & $-5,60 \pm 1,98$ & \\
Delta 1 sauna & Pretest - K2 posttest 1 & $-4,07 \pm 1,01$ & 0,031 \\
Delta 2 warm water & Pretest - K1 posttest 2 & $-6,66 \pm 1,57$ & \\
Delta 2 sauna & Pretest - K2 posttest 2 & $-6,23 \pm 1,50$ & 0,568 \\
Delta 3 warm water & K1 post test1- K2 posttest 1 & $-1,05 \pm 0,58$ & \\
Delta 3 sauna & K2 Post test1- K2 posttest 2 & $-2,16 \pm 1,08$ & 0,015 \\
\hline
\end{tabular}

Independent- $T$ test uses a significance level $\quad(p<0.05)$, delta 1 warm water and delta 1 sauna $\mathrm{p}=0.031$, delta 3 warm water and delta 3 sauna $\mathrm{p}=0.015 .(\mathrm{P}<0.05)$ Thus from the results of the study, it can be concluded that the decrease in blood lactic acid levels is greater in the warm water recovery than the aromatherapy sauna recovery.

\subsection{Lactic Acid Levels after Exercise}

In this study, subjects who were treated with submaximal physical activity were seen from their accumulation of lactic acid, those who carried out strenuous activities but in a short time. This situation causes anaerobic metabolism to occur. In anaerobic conditions, there is a reduction in ATP and accumulation of lactate as a metabolic waste product in the muscles. The average results of lactic acid levels 10 minutes after exercise are in table 5.2, which is 9.36 $\pm 1.82 \mathrm{~mol} / \mathrm{L}$, this proves that there is an increase in lactic acid levels as a result of anaerobic metabolism after subjects perform physical activities with $85 \%$ maximum heart rate will cause collection lactic acid in muscles. The reason for measuring blood lactic acid after recovery 10 minutes after physical activity is that peak levels of lactic acid occur 10 minutes after intensive training (Gollnick, 1986). This increase occurs because lactate is formed during physical activity and only diffuses into the blood 10 minutes afterward, with a recovery of 5 minutes in warm water sharply decreases lactic acid levels (Guyton, 1996).

In a very heavy activity condition, the energy required is obtained from anaerobic metabolism that is imperfect glucose metabolism with the final result in the form of 2 ATP plus residual products in the form of lactic acid. Residual production in the form of lactic acid, after dissociation, becomes lactic and $\mathrm{H}+$ is a strong acid. Increased $\mathrm{H}+$ is very influential on the appearance of skeletal muscle fatigue. Skeletal muscle fatigue caused by an increase in $\mathrm{H}+$ is proven by Wilmore's (1994) study which stated that human's muscle fatigue shows a very strong relationship between a decrease in the strength of muscle contraction in proportion to a decrease in the $\mathrm{pH}$ of muscle tissue. Research on skeletal muscle fibers illustrates that acidosis in muscle cells will reduce isometric strength and speed of muscle contraction to cause fatigue.

\subsection{Lactic Acid Levels after 5 Minutes of Recovery in Warm Water}

The mean value of lactic acid levels immediately after warm water recovery for 5 minutes for the warm water recovery group was $3.75 \pm 1.04 \mathrm{mMol} / \mathrm{L}$ while the aromatherapy sauna recovery group was $5.28 \pm 1.35 \mathrm{mMol} / \mathrm{L}$ (Table 5.2). 
According to Fox and Bowers (1998), exercises conducted with a high intensity approaching maximum then the dominant energy system is the anaerobic system. Oxygen debt as a result of the activities carried out will be fulfilled about 15 minutes after carrying out the activity (Bompa, 1994). During a lack of oxygen, a person must make recovery with active rest so the recovery will proceed quickly. This causes the lack of oxygen in the body will be filled quickly 3-5 minutes after the initial activity and the next 15-25 minutes will recover $50 \%$ and the body's condition will really recover normally after resting for approximately $60-90$ minutes.

Decreased blood lactic acid in group K1 (warm water recovery) was higher than group K2 (aroma sauna therapy recovery) because in warm water recovery there was a greater vasodilation so that oxygen supply to the striated muscles was also higher and would carry almost all acids lactate from the muscle diffuses into the blood and is immediately followed by a coriatic cycle, therefore, the lactic acid in the blood is recovered for 5 minutes after recovering warm water or 15 minutes after submaximal physical activity reaches a lower rate.

\subsection{Lactic Acid Levels 10 Minutes after Warm Water Recovery and Aromatherapy Sauna Recovery}

From the results of this study, the lactic acid level average 10 minutes after recovery for the warm water recovery group was $2.70 \pm 0.88 \mathrm{mMol} / \mathrm{L}$ and for the group of aromatherapy sauna recovery was $3.12 \pm 1.01 \mathrm{mMol} / \mathrm{L}$. This condition shows that after being given a recovery treatment with a different form of recovery that is active and passive from a homogeneous state of body weight and height and the same training load $85 \%$ of the maximum heart rate, the levels of lactic acid in the warm water recovery group are lower than in the aromatherapy recovery sauna. Lactic acid levels in the warm water recovery group decreased a lot $(6.66 \pm 1.57 \mathrm{mMol} / \mathrm{L})$ while the aromatherapy sauna recovery group experienced a slight decrease $(6.23 \pm 1.50 \mathrm{mMol} / \mathrm{L})$, as seen in table 5.4.

It is understood, that physical exercise will release energy in the form of heat. When body temperature rises, the metabolic rate will increase at a comparable speed. According to (Ganong, 2005), the main source of body heat is skeletal muscle. After physical exercise, the metabolic rate increases 5-20 times higher than normal for a relatively short period of time after recovery for 5 minutes at warm water temperature vasodilation occurs.

\subsection{The Decrease of Blood Lactic Acid Levels in Warm Water Recovery and Aromatherapy Sauna Recovery}

The value of the reduction in blood lactic acid levels 5 minutes after recovery in the warm water recovery group was $5.60 \mathrm{mMol} / \mathrm{L}$, whereas in the sauna recovery group the mean aromatherapy was $4.07 \mathrm{mMol} / \mathrm{L}$. The results of paired t-test analysts for decreasing levels of lactic acid in the two groups showed significant differences $(p<0.05)$. However, the decrease is not enough to restore lactate acid levels as in normal conditions around 1-2 mMol / L (Jansen, 1987). In general, to eliminate 95\% of the pile of lactic acid takes approximately 1 hour 15 minutes after maximum exercise. There are several organs that are capable of oxidizing lactic acid, but the striated muscle plays the biggest role. Most of the oxidation of lactic acid occurs in striated muscle with slow contractions. This is the reason why the decrease in lactic acid is faster in warm water recovery when compared to full rest (Fox, 1993). To clean lactic acid levels in the body is to more quickly by using mild activities than without doing any activity (Fox, 1993, Venom, 2007). 
In warm water recovery, vasodilation occurs both in arteries and veins. In arteries, the supply of oxygen to the muscles increases so that the availability of oxygen needed can change anaerobic conditions into aerobes, thereby fulfilling the oxygen debt in this case. When a person starts to breathe oxygen in a period of anaerobic metabolism, lactic acid is converted back to pyruvic acid and NADH plus $\mathrm{H}+$, most of it will be immediately oxidized to form large amounts of ATP. Vasodilation in the veins will facilitate the removal of lactate from muscle tissue to be converted back into pyruvic acid which occurs in the liver with the help of lactate dehydrogenase.

During warm water recovery, the body supplies enough oxygen so that it can be used for metabolic processes in the muscles together with pyruvic acid through the process of the Kreb cycle in a number of electron transports (Guyton \& Hall, 1995). From the Krebs cycle and electron transport system, the energy will be obtained to absorb ATP which has been used during the exercise. Thus, a number of lactic acid formed during the anaerobic glycolysis process does not disappear from the body until oxygen is available again lactic acid is converted into ATP or energy. After enough energy is available in the muscles, the condition becomes fresh and ready to do the exercise again, and with the recovery of warm water can shorten the recovery time (Chris Hodgson, 2006).

\section{Conclusion}

It can be concluded that the reduction in blood lactic acid levels with the warm water recovery (temperature $35^{\circ} \mathrm{C}-37^{\circ} \mathrm{C}$ ) is greater than the aromatherapy sauna recovery.

\section{References}

Afriwandi, (2007) Pengaruh Pemulihan aktif dan Pasif Terhadap Lamanya Perubahan Kadar Laktat Darah. Fakultas Kedokteran Universitas Andalas.

Ahmaidi S, (1996). Effect Recovery on Plasma Lactate and Anaerobic Power Following Repeated Intensive Exercise, Med Science Sport Exercise, 2 (4): 450-456.

Astrand PO, and Rodahl K, (1986). Text Book of Work Physiology Basic of Exercise, USA: McGraw -Hill Book Company, pp224-276.

Bompa TO, (1994). Theory and Methodology of Training: Kendall Hunt Publishing Company. Iowa. Pp 2-6.

Brooks GA, and Fahey TD, (1984). Exercise Physiology of Human Biogenetics and Its Applications. New York: John Willey and Sons, pp 701-705.

Burke EJ, (1980). Toward and Understanding of Human Performance, Second edition. New York. pp. 2-6.

Chris Hodgson, (2006). Effect of Active Recovery on Plasma Lactate Following Intensive Exercise, Journal of Science and Sports Medicine 5httpwww.jssm.org pp 97-105.

Christoper R, Mitchell and Brenard H, (2002). Effect of body temperature during exercise on skeletal muscle cytochrome C oxidase content. J Appl Physiology 93pp: 526-530, 2002.

Falk, (1995). Diambil pada 13 februari 2008. Journal of Endocrinology. 4(3),1995 dari http://www.endotxt.org/thermoregulation/neuroendo.html.

Federer, W.T., (1995). Experimental Design; Theory and Application, NewYork: Mac Millan Fox El, Bower RW, Foss ML (1993). The Physiological for Exercise and Sport, Lowa: WBC Brown and Benchmark, pp 13-37, 43-71 and 871-828

Ganong WF, (2005). Review of Medical Physiological. 20th Ed. New York: Lange Medical Books/Mcgraw Hill Medical Publishing Division. 
Good Win ML, (2007). Blood Lactate Measure and Analysis during Exercise: A Guide for Clinician, J of Diabetes Science and Technology (4) Pp:558-569.

Guyton A.C, \& JohnE.H, (2007). Text Book of Medical Physiology, 11th edition Elsevier Saunders, Philadelphia, Pennsylvania, pp 1063-1072,1129-1132, and 1139-1347.

Hanafiyah A, (1995), Rancangan Percobaan Teori dan Aplikasi, Fakultas keperawatan universitas Sriwijaya.

Higgins JE dan Kleimbaun AP, (1985). Design methodology for randomized clinical trials. USA: Family Health International, pp 24-25

Janssen PGJM, (1987). Training Lactate pulse-rate. Oulu Finland. Polar electroly Pub, 26, 5153 , and $57-58$.

Kent M, (1994). The Oxford Dictionary of Sport Science and Medicine, New York:OxfordUnivercity Press, pp. 75-77,144-145, and 384,411.

McArdle WD, Kacth FI, and VL, (1996). Qexercise Physiology: Energy, Nutrition and Human Performance. Lea \& Febiger. Philadelphia, Pp:106-107, 171-181.

Murray RK,.(2000). Harper's Biochemistry 25 ed. Appleton \& Lange. America 2000: 687-113.

Myers, R.D, (1984). Neurochemistry of thermoregulation. The Physiologist, 27, (1), $41-46$

Patellongi I. (1999) Pengaruh Intensitas Latihan Fisik Terhadap Kerusakan Jaringan. Disertasi. Program Pascasarjana Universitas Airlangga Surabaya.

Patellongi I. 2000 Fisiologi Olahraga. Ed. I Makassar ; Universitas Hasanuddin Pp:1-6, 59-73.

Pendergast DR,. (1988). The effect of body cooling oxygen transport during exercise, Med Sci sport Exercise, Pp : 171-176

Peni. (2008), Hydrotherapy di Klinik Dharma Daya Lestari Jakarta, info@hydrotherapyklinik.com diambil pada Tanggal 8 Oktober 2008.

Prasetyo Y. (2008). Pengaruh masase teknik friction pada tungkai setelah latihan fisik maksimal terhadap kecepatan pemindahan laktat. Tesis. Program Pasca Sarajana Universitas Airlangga Surabaya.

Rachmaniyah, (2009). Pengaruh pemulihan aktif di air hangat setelah aktivitas fisik sesaat terhadap penurunan kadar asam laktat tikus putih (rattusnorvegicus), Program Pasca Sarjana Fakultas Kedokteran Universitas Airlangga Surabaya.

Rushall BS and Pyke, (1980). Training For Sport And Fitness, 1 st ed Melbourne: Macmillan Co Australia, Pp. 15-20, 60-65.

Sherwood L, (2001), Human Physiology: From Cell to system, 2.Ed.international Thomson Publishing Inc.(10).

Sudarso, (2004). Akumulasi Asam Laktat \& Kelelahan Selama Berolahraga. Jurnal IKOR (1); 2:Pp: 70-78.

Sukarman R ,(1981). system energy predominan pada olahraga. Jakarta : KONI, hal 3-8

Taylor, P.M., (2002). Mencegah dan mengatasi Cedera Olahraga. Jakarta: PT Raja Grafindo Persada, pp. 222-223.

Westerblad H, Allen DG., and Lannergen J., (2000), Muscle Fatigue:lactic acid or inorganic phosphate the major cause. New PhysiolSci,17-21.

Wilmore JH, Costill DL, (1994) Physiology of Sport And Exercise. USA. 10th ed. US of America, Human Kinetics, 318-330.

Zainuddin M, (2000). Metodologi Penelitian Surabaya : Program Pasca Sarjana Universitas Airlangga Surabaya. 